\title{
Değişik Arkadaş Bitkilerin Yonca Silaj Kalitesine Etkisi
}

\author{
Hanife MUT ${ }^{1}$, Erdem GÜLÜMSER², Medine ÇOPUR DOĞRUSÖZ ${ }^{3}$, Uğur BAŞARAN4 \\ ${ }_{1,2}$ Bilecik Şeyh Edebali Üniversitesi, Ziraat ve Doğa Bilimleri Fakültesi, Tarla Bitkileri Bölümü, 11230, Bilecik, ${ }^{3,4}$ Yozgat Bozok Üniversitesi, \\ Ziraat Fakültesi, Tarla Bitkileri Bölümü, 66100, Yozgat \\ ${ }^{1}$ https://orcid.org/0000-0002-5814-5275, ${ }^{2}$ https://orcid.org/0000-0001-6291-3831, ${ }^{3 h t t p s: / / o r c i d . o r g / 0000-0002-9159-1699 ~}$ \\ ${ }^{4}$ https://orcid.org/0000-0002-6644-5892 \\ $\square$ : hanife.mut@bilecik.edu.tr
}

\section{ÖZET}

Bu çalışma yoncaya "YN" (Medicago sativa L.) farklı oranlarda ilave edilen (\% 100:0, 75:25, 50:50, 25:75) Macar fiği "MF" (Vicia pannonica Crantz), yem şalgamı "YŞ" (Brassica rapa L.) ve yulaf "Y" (Avena sativa L.) karışımlarının silaj kalitesinin belirlenmesi amacıyla yürütülmüştür. Hasat zamanı yalın yulafta süt olum, yalın yem şalgamında çiçeklenme, yalın Macar fiğinde alt baklaların oluştuğu dönemde, yalın yoncada ise \% 10 çiçeklenme döneminde yapılmıştır. Karışımlarda ise yoncanın hasat zamanı baz alınmıştır. Parçalama işleminden sonra materyaller 2 kg'llk kavanozlarda ağızları hava almayacak şekilde kapatılarak $25 \pm 2 \quad{ }^{\circ} C^{\prime}$ de 45 gün süre ile fermantasyona bırakılmıştır. Fermantasyon süresinin sonunda açılan silajlar örneklerinde; kuru madde (KM), $\mathrm{pH}$, ham protein (HP), laktik asit (LA), asetik asit (AA), bütürik asit (BA), potasyum (K), fosfor (P), kalsiyum (Ca), magnezyum (Mg) ve demir (Fe) içerikleri belirlenmiştir. Silajların Flieg puanlamalarına göre \% $75 \mathrm{YN}+25 \mathrm{Y}$ (97.80), \% 25YN+75YŞ (97.20), \% 50YN+50Y (96.80), \% 25YN+75Y (91.93) ile yalın yulaf (91.33) işlemleri en yüksek değere sahip olmuş ve silaj kalitesi bakımından çok iyi sınıfta yer almıştır. En yüksek LA oranı \% 6.570 ile \% 75YN+25Y, en düşük ise \% 0.780 ile \% $75 \mathrm{YN}+25 \mathrm{MF}$ silajlarından elde edilmiştir. Silajların AA asit değeri ise \% 0.033-0.283 arasında değişirken, BA tespit edilmemiştir. Silajların Flieg puanları ile ham protein oranları birlikte değerlendirildiğinde; yonca ile yem şalgamının ele alınan tüm oranlarında ve yulaf ile \% $75+25$ oranında yapılan silajların kalitesinin daha yüksek olduğu sonucuna varılmıştır.

\section{Effect of Different Companion Crops on Alfalfa Silage Quality}

\section{ABSTRACT}

Objective of this study was to determine silage quality of Hungarian vetch "HV" (Vicia pannonica Crantz), Turnip "T" (Brassica rapa L.) and Oat "O" (Avena sativa L.) added to Alfalfa "A" (Medicago sativa L.) with different proportions (100:0, 75:25, 50:50 ve 25:75\%). Harvest was done at milk dought stage for sole oat, flowering stage for sole turnip, exact shape formation period of seeds in the bottom pods for sole Hungarian vetch, $10 \%$ flowering stage for sole alfalfa. Besides, the harvest of mixtures was done based on alfalfa. Then, plants were ensiled in $2 \mathrm{~kg}$ plastic jars and fermentation at $25 \pm 2{ }^{\circ} \mathrm{C}$ over 45 days. The silage samples were opened at the end of the fermentation period and dry matter ratio $(\mathrm{DM}), \mathrm{pH}$, crude protein ratio $(\mathrm{CP})$, lactic acid (LA), acetic acid (AA), butyric acid (BA), potassium (K), phosphorus $(\mathrm{P})$, calcium $(\mathrm{Ca})$, magnesium $(\mathrm{Mg})$ and iron $(\mathrm{Fe})$ were determined. According to the Flieg score, $75 \mathrm{~A}+25 \mathrm{O} \%$ (97.80), 25A+75T\% (97.20), $50 \mathrm{~A}+50 \mathrm{O} \%(96.80), 25 \mathrm{~A}+75 \mathrm{O} \%(91.93)$ and sole oat (91.33) silages have the highest value and, they were in good quality class of silage. The highest LA was determined in $75 \mathrm{~A}+25 \mathrm{O} \%(6.570 \%)$, while the lowest was $75 \mathrm{~A}+25 \mathrm{HV} \%(0.780 \%)$. The AA acid ranged between $0.033^{-}$ $0.283 \%$, and the BA was not found. As a result, when the Flieg score

\section{Araştırma Makalesi}

\section{Makale Tarihçesi}

Geliş Tarihi : 02.01 .2020

Kabul Tarihi : 02.04.2020

Anahtar Kelimeler
Silaj
Yonca
Macar fiği
Yem şalgamı
Yulaf

\section{Research Article}

$\begin{array}{ll}\text { Article History } \\ \text { Received } & : 02.01 .2020 \\ \text { Accepted } & : 02.04 .2020\end{array}$

Keywords
Silage
Alfalfa
Hungarian vetch
Turnip
Oat


and crude protein ratios was evaluated together, it was concluded that suitable silage quality determined relatively high of alfalfa with all turnip mixture and with oat at $75+25 \%$ mixture.

To Cite: Mut H, Gülümser E, Çopur Doğrusöz M, Başaran, U 2020. Değişik Arkadaş Bitkilerin Yonca Silaj Kalitesine Etkisi. KSÜ Tarım ve Doğa Derg 23 (4): 975-980. DOI: 10.18016/ksutarimdoga.vi.669234.

\section{Gİiș}

Kaba yemin nitelikli, bol ve ucuz olması, genelde daha pahalı olan kesif yemlerin kullanımını en aza indirirken, diğer taraftan işletmeye büyük ekonomik kazanç sağlamaktadır. Nitekim bir işletmede toplam masrafların yaklaşık \%70'ini yem giderleri oluştururken, bu yem giderlerinin \%80'ini kaba yemler oluşturmaktadır (Harmanşah, 2018). Diğer taraftan kaba yemler hayvanın sindirim sisteminin düzgün çalışması ve oluşan besin dengesiyle nitelikli ve bol ürün alınması açısından önem teşkil etmektedir.

En önemli kaba yem kaynaklarından biri olan yonca dünyada olduğu gibi Türkiye'de de en fazla yetiştirilen yem bitkisidir. Türkiye'de 2018 TÜİK verilerine göre, 635 bin ha yonca ekim alanı olup, bu ekim alanlarından 17.5 milyon ton yeşil ot üretimi sağlanmaktadır (Anonim, 2018a). Yonca diğer yem bitkilerine oranla kalitesinin yüksek olması, kolay adapte olması ve ekonomik ömrünün uzun olması gibi sebeplerinden dolayı daha fazla tercih edilmektedir. Son yıllarda yaşanan iklim değişikliklerinden dolayı yoncayı kurutmak zor hale gelmiş ve bu nedenle de üreticiler bitkinin silaj yapımına yönelmiştir (Ergin, 2019). Nitekim Türkiye'de 2017 ve 2018 yllları yıllık toplam yağış rejimi uzun yıllar ortalamasından sirasıyla \% 100 ve \% 17 oranında daha fazla olmuştur (Anonim, 2018b). Bu sayede hem bitkinin kurutulmasında harcanan zamandan tasarruf edilmiş hem de kurutmada meydana gelebilecek kayıpların önüne geçilmiştir. Kutlu (2002) yaptığı bir çalışmada kuru ot olarak değerlendirilen baklagillerde kuru madde kaybının \% 30 iken, silaj olarak değerlendirildiğinde bu kaybın \% 5'e indiğini, sindirilebilir protein kaybının ise \% 35'lerden \% 5'e kadar düştüğünü bildirmiştir.

Baklagillerin silajları kuru otlarına kıyasla süt inekleri için daha yüksek besleme değerine sahiptirler. Ancak, yüksek protein içeriği ve yüksek tamponlama kapasitelerinden dolayı buğdaygillere göre silaj yapılması daha zordur (Keleş ve ark., 2013). Zira, baklagil bitkilerinin enerjice düşük olmaları laktik asit (LA) üreten bakterilerin gelişmesine engel teşkil etmekte ve aynı zamanda suda çözünen azotlu maddelerin bazik olması fermantasyon sırasında üretilen asidi nötrleştirdiğinden $\mathrm{pH}$ istenen düzeyde olmamaktadır. Diğer taraftan silaj yapımında kullanılan tahilların (yulaf, misır, sorgum, vb.) ise ham protein (HP) oranı düşüktür. Bu da silaj kalitesini düşürmektedir. $\mathrm{Bu}$ yüzden tahıllar ve baklagillerin karışık olarak silaj yapılması, silo yeminin nem içeriğinin düşürülmesi, LA oluşumunu teşvik edilmesi ve protein oranının yükseltilmesi açısından önem teşkil etmektedir.

Yoncanın silaj olarak değerlendirilmesi yaprak kayıplarının azalması nedeniyle daha fazla besin maddesinin korunmasina yardımcı olmakta ve ayrica kurutma için bitki sahada daha az zaman geçirdiğinden hava hasarı da önlenmiş olmaktadır. Baklagil silajlarında problem olan düşük kuru madde içerikleri, ya kuru madde oranını arttırmak için soldurarak silolama (ki yaygin bir şekilde kullanılmaktadır) ya da karışı ekim şeklinde yapılacak yetiştiricilik ile desteklenmektedir. Bu çalışmada yonca ile karışım şeklinde Macar fiği (kışlık ve tek yıllık olması), yem şalgamı (bol yaprak içermesi) ve yulaf (serin iklim tahılları içerisinde en yüksek kalite değerine sahip olması) yetiştirilerek elde edilen silajın kalite içerikleri tespit edilmiştir.

\section{MATERYAL ve YÖNTEM}

Çalışmada materyal olarak yoncada (Medicago sativa L.) "Kayseri", Macar fiğinde (Vicia pannonica Crantz) "Altınova 2002", yem şalgamında (Brassica rapa L.) "Lenox" ve yulafta (Avena sativa L.) "Çekota" çeşitleri kullanılmıştır. Yonca ile arkadaş bitkiler yalın olarak ve 3 farklı karışım oranı (\% 75:25, 50:50, 25:75) ile ekilmiştir.

Çalışmanın yürütüldüğü Bilecik ilinin 2018-2019 yılları arasına ait sıcaklık, yağış ve nispi nem değerleri Bilecik Meteoroloji Bölge Müdürlügü̈nden alınmıştır. Bilecik ili uzun yıllar ortalaması olarak yağış toplamı $424.7 \mathrm{~mm}$ iken, 2018-2019 vejetasyon döneminde ise $377.4 \mathrm{~mm}$ olmuştur. Uzun yıllar sıcaklık ortalaması $10.5{ }^{\circ} \mathrm{C}, 2018-2019$ yllinda ise $11.3{ }^{\circ} \mathrm{C}$ olarak tespit edilmiştir. İlin uzun yıllar ve 2018-2019 yılı ortalama nispi nem değerleri ise sirasıyla \% 68.8 ve \% 70.9 olmuştur (Çizelge 1).

Deneme alanının toprak özellikleri, killi tınlı bünyeye sahip, $\mathrm{pH}$ bakımından hafif alkali (7.72), orta seviyede kireçli (\% 7.67) ve hafif tuzlu (\% 0.036) bir yapıya sahiptir. Deneme toprağının fosfor içeriği (24.94 $\mathrm{kg} / \mathrm{da})$ ve potasyum değeri fazla olup $(161.7 \mathrm{~kg} / \mathrm{da})$, organik madde miktarı ise az (\% 1.32) olarak belirlenmiştir.

Çalışma Bilecik Şeyh Edebali Üniversitesi, Ziraat ve Doğa Bilimleri Fakültesi, Tarımsal Araştırma ve Uygulama arazisinde Tesadüf Blokları Deneme desenine göre 3 tekerrürlü olarak kurulmuştur. İlk olarak arkadaş bitkiler sıra arası $20 \mathrm{~cm}$, sıra uzunluğu $4 \mathrm{~m}$ ve 4 sıra olacak şekilde ekilmiştir. Daha sonra deneme alanı belli olan arazi üzerine yonca el ile 
serpme olarak ekilmiştir. Tohumluk miktarı yoncada $3 \mathrm{~kg} / \mathrm{da}$, Macar fiğinde $10 \mathrm{~kg} / \mathrm{da}$, yem şalgamında 1 $\mathrm{kg} / \mathrm{da}$ ve yulafta $20 \mathrm{~kg} / \mathrm{da}$ olarak hesaplanmıştır. Denemede ekim (31.10.2018) ile birlikte tüm parsellere dekara $8 \mathrm{~kg} \mathrm{P}_{2} \mathrm{O}_{5}$ gelecek şekilde DAP gübresi uygulanmıştır. Hasat işlemi yoncada \% 10 çiçeklenme döneminde, Macar fiğinde alt baklaların oluştuğu dönemde, yem şalgamında çiçeklenme ve yulafta süt olum döneminde gerçekleştirilmiştir.
Karışımlarda ise yoncanın hasat zamanı baz alınmıştır. Hasat edilen taze ot örnekleri (baklagiller 24 saat soldurulmuştur (Dumlu Gül ve ark., 2013)) 2 cm boyutunda parçalanmış ve karışım oranları da dikkate alınarak 2 kg'llk plastik kavanozlara iyice sıkıştırılıp, ağızları hava almayacak şekilde kapatılarak $25 \pm 2^{\circ} \mathrm{C}$ 'de 45 gün süre ile fermantasyona bırakılmıştır.

Çizelge 1. Bilecik ili uzun yıllar ve 2018-2019 yılları arası iklim verileri

Table 1. Meteorological data of Bilecik in the long-term and 2018-2019 year

\begin{tabular}{|c|c|c|c|c|c|c|}
\hline \multirow{2}{*}{ Aylar (Months) } & \multicolumn{2}{|c|}{$\begin{array}{l}\text { Ortalama sicaklik }\left({ }^{\circ} \mathrm{C}\right) \\
\text { (Average temperature) }\end{array}$} & \multicolumn{2}{|c|}{$\begin{array}{l}\text { Toplam yağış }(\mathrm{mm}) \\
\text { (Total precipitation) }\end{array}$} & \multicolumn{2}{|c|}{$\begin{array}{c}\text { Ortalama nispi nem (\%) } \\
\text { (Average moisture) }\end{array}$} \\
\hline & $\begin{array}{c}\text { UYO* } \\
\text { (Long-term) }\end{array}$ & $2018-19$ & $\begin{array}{c}\text { UYO* } \\
\text { (Long-term) }\end{array}$ & 2018-19 & $\begin{array}{c}\mathrm{UYO}^{*} \\
\text { (Long-term) }\end{array}$ & $2018-19$ \\
\hline Eylül (September) & 18.4 & 19.6 & 22.9 & 77.2 & 62.9 & 69.1 \\
\hline Ekim (October) & 13.8 & 14.8 & 40.5 & 23.4 & 68.5 & 73.6 \\
\hline Kasım (November) & 9.0 & 9.7 & 37.2 & 14.2 & 71.1 & 75.9 \\
\hline Aralık (December) & 4.5 & 3.6 & 55.9 & 33.9 & 76.0 & 85.0 \\
\hline Ocak (January) & 2.4 & 3.5 & 50.1 & 5.3 & 76.5 & 77.1 \\
\hline Şubat (February) & 3.7 & 4.7 & 42.0 & 1.8 & 73.2 & 75.2 \\
\hline Mart (March) & 6.4 & 7.6 & 47.3 & 13.2 & 69.3 & 61.3 \\
\hline Nisan (April) & 11.5 & 10.8 & 41.8 & 30.8 & 64.2 & 65.4 \\
\hline Mayıs (May) & 16.1 & 17.9 & 47.7 & 24.3 & 64.5 & 59.9 \\
\hline Haziran (June) & 19.9 & 21.3 & 39.3 & 153.3 & 62.0 & 66.7 \\
\hline Ortalama (Average) & 10.5 & 11.3 & & & 68.8 & 70.9 \\
\hline Toplam (Total) & & & 424.7 & 377.4 & & \\
\hline
\end{tabular}

*UYO:Uzun yıllar ortalaması (1939-2019 yıllar arasını kapsamaktadır).

Kırk beş günlük fermantasyon dönemi sonrasında açılan silajlardan $20 \mathrm{~g}$ örnek alınarak üzerine $100 \mathrm{ml}$ saf su ilave edilmiş ve blender yardımı ile iyice karıştırılarak filtre kâğıdından süzülmüştür. Örneklerin pH'sı dijital $\mathrm{pH}$ metre ile ölçülmüştür (Başaran ve ark., 2018).

Açılan silajlardan alınan örnekler yaş olarak tartıldıktan sonra etüve konularak $105{ }^{\circ} \mathrm{C}$ derecede sabit ağırlığa gelinceye kadar kurutulmuş ve kuru örnek ağırlığı yaş örnek ağırlığına oranlanarak kuru madde oranları belirlenmiştir. Kuru madde (KM) ve pH değerleri belirlenen silaj örneklerinde aşağıdaki formül yardımı ile Flieg puanları hesaplanmıştır. Hesaplanan Flieg puanına göre ise silaj kalite sınıfları belirlenmiş̧tir. Buna göre, Flieg puanı 0-20 arasında kötü, 21-40 arasında düşük, 41-60 arasında orta, 61-80 arasında iyi ve 81-100 arasında ise çok iyi sınıfta yer almıştır.

Flieg Puanı: $((220+(2 \times \% \mathrm{KM}-15)-40 \times \mathrm{pH})($ Kılıç, 1984).

Silaj örnekleri $60{ }^{\circ} \mathrm{C}$ 'de sabit ağırlığa gelene kadar kurutulmuş ve laboratuvarda $1 \mathrm{~mm}$ elek çapına sahip değirmende öğütülerek analize hazır duruma getirilmiştir. Örneklerin Kjeldahl yöntemi ile azot içerikleri belirlenmiş ve bulunan değer 6.25 katsayısı ile çarpılıp (HP) tespit edilmiştir (Başaran ve ark., 2018).

Silaj örneklerinde potasyum (K), fosfor (P), kalsiyum $(\mathrm{Ca})$, magnezyum $(\mathrm{Mg})$ ve demir $(\mathrm{Fe})$ içerikleri İndüktif
Eşleşmiş Plazma-Kütle Spektrometre (ICP-MS) cihazı, LA, asetik asit (AA) ve bütürik asit (BA) analizleri, yüksek performanslı sıvı kromatografi (HPLC) cihazı ile (Shimadzu, Kyoto, Japonya, kılcal sütun $5 \mu m \times 4.6$ $\mathrm{mm} \times 250 \mathrm{~mm}$, Japon ve $40^{\circ} \mathrm{C}$ sicaklıkta) belirlenmiştir (Başaran ve ark., 2018).

Elde edilen sonuçlar SPSS 18.0 istatistik paket programı kullanılarak Tesadüf Parselleri Deneme Desenine göre analiz edilmiş, grup ortalamaları arasındaki farklılıkların karşılaştırılmasında Duncan testi kullanılmıştır.

\section{BULGULAR ve TARTIŞMA}

Farklı tohum oranlarında ekilen yonca "YN" ile Macar fiği "MF", yem şalgamı "YŞ" ve yulaf "Y" karışımlarından elde edilen silajların $\mathrm{pH}$ ve kuru madde oranına (KM) göre Flieg puanları ve kalite sınıfları Çizelge 2'de verilmiştir. Buna göre, $\mathrm{KM}$, $\mathrm{pH}$ ve Flieg özellikleri üzerinde karışım oranlarının etkisi çok önemli $(\mathrm{P}<0.01)$ olmuştur.

En yüksek KM oranı \% 36.00 ile \% $75 \mathrm{YN}+25 \mathrm{Y}$, en düşük ise \% 26.50 ile yalın yonca silajından elde edilmiştir. Silajların pH içerikleri 4.11 (yalın yulaf) ile 5.16 (yalın Macar fiği) arasında değişmiştir. Filya (2001) silaj üzerine olumsuz etkide bulunan enterobacteria mikroorganizmalarının çoğalmaması için pH'nın 5'in altına, clostridial sporlarının çoğalmaması için ise 4.6'nın altına düşmesi gerektiğini bildirmiştir. Çalışmada \% 100MF， \% 100YŞ, \% 
$50 \mathrm{YN}+50 \mathrm{YŞ}$ ve $\% 25 \mathrm{YN}+75 \mathrm{MF}$ dışında kalan tüm silajlar bu kritik değerin altında yer almıştır (Çizelge 2). Alaca ve Parlak (2017) misır, sorgum sudanotu melezi ile soya, börülce ve sakız fasulyesinin farklı karışımlarının silaj kalitelerini belirledikleri çalışmada, en yüksek pH değerini yalın sakız fasulyesinde (5.17), en düşük ise yalın mısır silajında (3.08) olduğunu bildirmiştir.

Çizelge 2. Silajlarının pH ve kuru madde oranına göre Flieg puanları ve kalite sınıfları

Table 2. Flieg score and quality class of silages based on $\mathrm{pH}$ and dry matter ratio

\begin{tabular}{|c|c|c|c|c|}
\hline $\begin{array}{l}\text { Karışımlar } \\
\text { (Mixtures) }\end{array}$ & $\begin{array}{c}\mathrm{KM}^{* *} \\
\text { (Dry matter ratio) }\end{array}$ & $\mathrm{pH}^{* *}$ & $\begin{array}{c}\text { Flieg puanı }^{* *} \\
\text { (Flieg score) }\end{array}$ & $\begin{array}{c}\text { Kalite sinıfi } \\
\text { (Quality class) }\end{array}$ \\
\hline 100YN (100A) & $26.50 \mathrm{f}$ & $4.43 \mathrm{~d}$ & 80.80 cde & İyi \\
\hline $100 \mathrm{MF}(100 \mathrm{HV})$ & $29.00 \mathrm{de}$ & $5.16 \mathrm{a}$ & $56.60 \mathrm{~g}$ & Orta \\
\hline 100YŞ (100T) & 28.00 ef & $4.62 \mathrm{c}$ & $76.20 \mathrm{def}$ & İyi \\
\hline $100 \mathrm{Y}(1000)$ & $32.50 \mathrm{~b}$ & $4.11 \mathrm{e}$ & $91.33 \mathrm{ab}$ & Çok iyi \\
\hline $75 \mathrm{YN}+25 \mathrm{MF}(75 A+25 H V)$ & 29.50 cde & $4.43 \mathrm{~d}$ & $87.00 \mathrm{bc}$ & Çok iyi \\
\hline $75 \mathrm{YN}+25 \mathrm{YSS}(75 A+25 T)$ & 29.50 cde & $4.50 \mathrm{~cd}$ & $84.00 \mathrm{bcd}$ & Çok iyi \\
\hline $75 \mathrm{YN}+25 \mathrm{Y}(75 A+25 O)$ & $36.00 \mathrm{a}$ & $4.48 \mathrm{~cd}$ & $97.80 \mathrm{a}$ & Çok iyi \\
\hline $50 \mathrm{YN}+50 \mathrm{MF}(50 \mathrm{~A}+50 \mathrm{HV})$ & 28.00 ef & $4.40 \mathrm{~d}$ & $85.00 \mathrm{bcd}$ & Çok iyi \\
\hline $50 \mathrm{YN}+50 \mathrm{YSS}(50 \mathrm{~A}+50 T)$ & 28.00 ef & $4.66 \mathrm{c}$ & 74.80 ef & İyi \\
\hline $50 \mathrm{YN}+50 \mathrm{Y}(50 A+500)$ & $29.00 \mathrm{de}$ & $4.16 \mathrm{e}$ & $96.80 \mathrm{a}$ & Çok iyi \\
\hline $25 \mathrm{YN}+75 \mathrm{MF}(25 \mathrm{~A}+75 \mathrm{HV})$ & $30.00 \mathrm{~cd}$ & $4.89 \mathrm{~b}$ & $69.27 \mathrm{f}$ & İyi \\
\hline $25 \mathrm{YN}+75 \mathrm{YSS}(25 A+75 T)$ & 28.00 ef & $4.10 \mathrm{e}$ & $97.20 \mathrm{a}$ & Çok iyi \\
\hline $25 \mathrm{YN}+75 \mathrm{Y}(25 A+75 O)$ & & $4.51 \mathrm{~cd}$ & $91.93 \mathrm{ab}$ & Çok iyi \\
\hline
\end{tabular}

(**) 0.01 düzeyinde önemli; YN: Yonca, MF: Macar fiği; YŞ: Yem şalgamı; Y: Yulaf; KM: Kuru madde oranı; A; Alfalfa; HV: Hungarian vetch; T: Turnip; O: Oat.

En yüksek Flieg puanı 97.80 ile \% 75YN+25Y, 97.20 ile $\% 25 \mathrm{YN}+75 \mathrm{YSS}, 96.80$ ile \% 50YN+50Y, 91.93 ile \% $25 \mathrm{YN}+75 \mathrm{Y}$ ve 91.33 ile yalın yulaf, en düşük ise 56.60 ile yalın Macar fiği silajlarından elde edilmiştir. Çalışmada belirlenen tüm silajlar orta, iyi ve çok iyi kalite sınıfında yer almıştır. Başaran ve ark. (2018)'nın mürdümük ile arpa ve yulaf karışımlarının silaj kalitelerinin belirlenmesi amacıyla yaptıkları çalışmada Flieg puanları 61.80 ile 87.40 arasında değişirken, silajların kalite sınıflar ise iyi ve çok iyi kalite arasında yer almıştır.

Yoncanın Macar fiği, yem şalgamı ve yulaf ile farklı karışımlarından elde edilen silajlarında belirlenen HP ve LA oranları Cizelge 3'de verilmiştir. Buna göre karışım oranlarının etkisi HP ve LA asit oranları üzerinde çok önemli $(\mathrm{P}<0.01)$, AA üzerinde ise önemsiz olmuştur (Çizelge 3). En yüksek HP oranı \% 20.92 ile $\% 75 \mathrm{YN}+25 \mathrm{MF}$, en düşük ise $\% 10.28$ ile yalın yulaf silajlarından elde edilmiştir. Baklagiller tahıllara oranla daha yüksek ham protein oranına sahiptirler. Dolayısıyla çalışmada yalın yonca ve Macar fiği silajlarının yem şalgamı ve yulafa oranla daha yüksek HP oranına sahip olduğu görülmektedir. Ayrıca karışımlarda yulaf ve yem şalgamı oranı arttığında HP düşmüştür. (Çizelge 3). Farklı araştırıcılar tarafından baklagil tahıl karışımları ile yapılan silajlarda HP oranı \% 7.51-22.68 arasında değişmiştir (Başaran ve ark., 2018; Can ve ark., 2019).

En yüksek LA oranı \% 6.570 ile \% $75 \mathrm{YN}+25 \mathrm{Y}$, en düşük ise \% 0.780 ile \% 75YN+25MF silajından elde edilmiştir. Karışımların AA değeri ise \% $0.033-0.283$ arasında değişirken, çalışmada bütürik aside rastlanılmamıştır. Yulafın bulunduğu silajlara ait LA içeriği diğer silajlara oranla daha yüksek olmuştur
(Çizelge 3). Bu durum yulafın suda çözünebilir karbonhidrat (SÇK) bakımından zengin olması ve fermantasyonu teşvik ederek laktik asit seviyesini hızlı bir şekilde yükseltmesinden kaynaklanmaktadır. Geren ve Kavut (2009) bazı misır ve sorgum türlerinin silaj kalitelerinin belirlenmesi amacıyla yaptıkları çalışmada mısırın LA oranının sorguma oranla daha yüksek olduğunu bildirmiştir.

Silajın kalitesinin tespit edilmesinde fermantasyon sonucunda ortaya çıkan organik asitlerin saptanması çok önemlidir. Bu organik asitlerden BA (tereyağı asidi) bakterileri proteinleri parçalayarak amin ve amonyağın açığa çıkmasına ve dolayısıyla da protein değerinin düşmesine neden olurlar. Bu yüzden silajda bütürik asit hiç istenmez. Asetik asit (sirke asidi) silajın hava aldığının ve bozulduğunun göstergesi olup, silo yeminde genelde bir miktar bulunmaktadır. Laktik asidin (süt asidi) ise silajda fazla olması tercih edilir (Uygur, 2019). Bu itibarla iyi bir silajda süt asidinin $\% 2$ ve üzerinde, sirke asidinin ise \% 0.3-0.8 ise arasında olması istenir (Alçiçek ve Özkan, 1996). Çalışmada, yalın Macar fiği ile yonca + Macar fiği karışımları dışında kalan tüm silajlar verilen değerler arasında olmuştur (Çizelge 3).

Farklı tohum oranlarında ekilen yonca ile Macar fiği, yem şalgamı ve yulaf karışımlarından elde edilen silajların $\mathrm{K}, \mathrm{P}, \mathrm{Ca}, \mathrm{Mg}$ ve $\mathrm{Fe}$ içerikleri Çizelge 4'te verilmiştir. $\mathrm{K}, \mathrm{P}, \mathrm{Ca}, \mathrm{Mg}$ ve Fe içerikleri bakımından muameleler arasındaki farklılıklar tüm gruplarda önemli $(\mathrm{P}<0.01)$ olmuştur (Çizelge 4).

En yüksek $\mathrm{K}$ istatistiksel olarak aynı grupta yer alan yalın Macar fiği (\% 2.754), \% 75YN+25Y (\% 3.047), $\% 50 \mathrm{YN}+50 \mathrm{Y}(\% 2.730), \% 25 \mathrm{YN}+75 \mathrm{YS}$ (\% 2.765) ve \% $25 \mathrm{YN}+75 \mathrm{Y}(\% 2.607)$ karışımlarından, en düşük ise \% 
1.503 ile yalın yem şalgamı silajından elde edilmiştir (Çizelge 4). Tejeda ve ark. (1985) ruminant hayvanlar için yemlerdeki $\mathrm{K}$ içeriğinin en az \% 0.8 olması gerektiğini bildirmiştir. Çalışmada tüm silajlarda belirlenen $\mathrm{K}$ içeriği istenen seviyenin üzerinde olmuştur. Gülümser ve ark. (2019) börülce ve soya üzerine ilave edilen arpa kırması ile melasın silaj kalitesine etkisini inceledikleri çalışmada, silajların K içeriği \% 1.520-2.783 arasında değişmiştir.

Silajların P, Ca ve Mg içerikleri ise sırasıyla \% 0.267-
0.797, \% 0.506-1.207 ve \% 0.227-0.448 arasinda değişmiştir (Çizelge 4). Hayvanların makro besin ele menti ihtiyacının karşılanması için kaba yemlerde $\mathrm{P}$ oranını \% 0.21, Ca oranının \% 0.3 ve $\mathrm{Mg}$ oranının \% 0.1 olması gerekir (Kidambi ve ark., 1989). Çalışmada tüm işlemlerde belirlenen değerler istenen düzeyin üzerinde olmuştur. Can ve ark. (2019) orman üçgülü yulaf karışımlarının silaj kalitesinin belirledikleri çalışmada silajların $\mathrm{P}, \mathrm{Ca}$ ve $\mathrm{Mg}$ içerikleri sırasıyla \% $0.232-0.301, \% 0.300-1.117$ ve $\% 0.118-0.309$ arasinda değişmiştir.

Çizelge 3. Silajların, ham protein, laktik ve asetik oranları (\%)

Table 3. Crude protein, lactic acid and acetic acid ratios of silages

\begin{tabular}{|c|c|c|c|}
\hline Karışımlar (Mixtures) & $\mathrm{HP}^{* *}$ (Crude protein) & LA ** (Lactic acid) & AA (Acetic acid) \\
\hline 100YN (100A) & $19.37 \mathrm{~b}$ & $4.302 \mathrm{~cd}$ & 0.048 \\
\hline $100 \mathrm{MF}(100 \mathrm{HV})$ & $16.93 \mathrm{ef}$ & $1.255 \mathrm{fg}$ & 0.161 \\
\hline 100YŞ (100T) & $14.37 \mathrm{~g}$ & $2.889 \mathrm{e}$ & 0.115 \\
\hline $100 \mathrm{Y}(1000)$ & $10.28 \mathrm{~h}$ & $5.042 \mathrm{bc}$ & 0.099 \\
\hline $75 \mathrm{YN}+25 \mathrm{MF}(75 \mathrm{~A}+25 \mathrm{HV})$ & $20.92 \mathrm{a}$ & $0.780 \mathrm{~g}$ & 0.283 \\
\hline $75 \mathrm{YN}+25 \mathrm{YS}(75 A+25 T)$ & $18.25 \mathrm{~cd}$ & $3.585 \mathrm{de}$ & 0.052 \\
\hline $75 \mathrm{YN}+25 \mathrm{Y}(75 A+25 O)$ & $18.11 \mathrm{~cd}$ & $6.570 \mathrm{a}$ & 0.033 \\
\hline $50 \mathrm{YN}+50 \mathrm{MF}(50 \mathrm{~A}+50 \mathrm{HV})$ & $18.97 \mathrm{bc}$ & $1.889 \mathrm{f}$ & 0.139 \\
\hline $50 \mathrm{YN}+50 \mathrm{YS}(50 A+50 T)$ & $17.71 \mathrm{de}$ & $3.262 \mathrm{de}$ & 0.117 \\
\hline $50 \mathrm{YN}+50 \mathrm{Y}(50 A+500)$ & $13.94 \mathrm{~g}$ & $5.004 \mathrm{bc}$ & 0.099 \\
\hline $25 \mathrm{YN}+75 \mathrm{MF}(25 A+75 H V)$ & $16.78 \mathrm{ef}$ & $1.607 \mathrm{fg}$ & 0.093 \\
\hline $25 \mathrm{YN}+75 \mathrm{YS}(25 A+75 T)$ & $16.40 \mathrm{f}$ & $3.567 \mathrm{de}$ & 0.101 \\
\hline $25 \mathrm{YN}+75 \mathrm{Y}(25 A+75 O)$ & $13.46 \mathrm{~g}$ & $5.486 \mathrm{~b}$ & 0.073 \\
\hline
\end{tabular}

$(* *) 0.01$ düzeyinde önemli; YN: Yonca, MF: Macar fiği; YŞ: Yem şalgami; Y: Yulaf; HP: Ham protein oranı; LA; Laktik asit; AA: Asetik asit; A; Alfalfa; HV: Hungarian vetch; T: Turnip; O: Oat.

Çizelge 4. Silajlarının K, P, Ca, Mg (\%) ve Fe (ppm) oranları

Table. 4. K, P, Ca, $\mathrm{Mg}(\%)$ and $\mathrm{Fe}(\mathrm{ppm})$ ratios of silages

\begin{tabular}{|c|c|c|c|c|c|}
\hline Karışımlar (Mixtures) & $\begin{array}{l}\mathrm{K}^{* *} \\
\text { (Potassium) }\end{array}$ & $\begin{array}{l}\mathrm{P}^{* * *} \\
\text { (Phosphorus) }\end{array}$ & $\begin{array}{l}\mathrm{Ca}^{* *} \\
\text { (Calcium) }\end{array}$ & $\begin{array}{l}\text { Mg** } \\
\text { (Magnesium) }\end{array}$ & $\begin{array}{l}\mathrm{Fe}^{* *} \\
\text { (Iron) }\end{array}$ \\
\hline $100 \mathrm{YN}(100 \mathrm{~A})$ & $2.480 \mathrm{bc}$ & $0.484 \mathrm{a}-\mathrm{d}$ & $0.912 \mathrm{bc}$ & $0.284 \mathrm{cde}$ & $42.420 \mathrm{bc}$ \\
\hline $100 \mathrm{MF}(100 \mathrm{HV})$ & $2.754 \mathrm{ab}$ & $0.713 \mathrm{a}$ & $1.016 \mathrm{abc}$ & $0.227 \mathrm{e}$ & $60.716 \mathrm{a}$ \\
\hline 100YŞ (100T) & $1.503 \mathrm{e}$ & $0.267 \mathrm{~d}$ & $0.506 \mathrm{e}$ & $0.246 \mathrm{de}$ & $31.295 \mathrm{~d}$ \\
\hline $100 Y(1000)$ & $1.666 \mathrm{de}$ & $0.336 \mathrm{~cd}$ & $0.541 \mathrm{de}$ & 0.290 cde & $36.287 \mathrm{~cd}$ \\
\hline $75 \mathrm{YN}+25 \mathrm{MF}(75 \mathrm{~A}+25 \mathrm{HV})$ & $2.079 \mathrm{~cd}$ & $0.661 \mathrm{ab}$ & $0.816 \mathrm{c}$ & $0.413 \mathrm{ab}$ & $47.725 \mathrm{~b}$ \\
\hline $75 \mathrm{YN}+25 \mathrm{YSS}(75 A+25 T)$ & $2.481 \mathrm{bc}$ & $0.624 \mathrm{abc}$ & $0.110 \mathrm{ab}$ & $0.448 \mathrm{a}$ & $45.887 \mathrm{bc}$ \\
\hline $75 \mathrm{YN}+25 \mathrm{Y}(75 A+25 O)$ & $3.047 \mathrm{a}$ & $0.797 \mathrm{a}$ & $1.207 \mathrm{a}$ & $0.334 \mathrm{bcd}$ & $51.383 \mathrm{ab}$ \\
\hline $50 \mathrm{YN}+50 \mathrm{MF}(50 \mathrm{~A}+50 \mathrm{HV})$ & $2.359 \mathrm{bc}$ & $0.541 \mathrm{ad}$ & $0.877 \mathrm{bc}$ & 0.293 cde & $43.481 \mathrm{bc}$ \\
\hline $50 \mathrm{YN}+50 \mathrm{YSS}(50 A+50 T)$ & $2.227 \mathrm{bc}$ & $0.376 \mathrm{bcd}$ & $0.775 \mathrm{~cd}$ & $0.369 \mathrm{abc}$ & $42.975 \mathrm{bc}$ \\
\hline $50 \mathrm{YN}+50 \mathrm{Y}(50 A+500)$ & $2.730 \mathrm{ab}$ & $0.655 \mathrm{ab}$ & $1.020 \mathrm{abc}$ & 0.301 cde & $51.766 \mathrm{ab}$ \\
\hline $25 \mathrm{YN}+75 \mathrm{MF}(25 A+75 H V)$ & $2.500 \mathrm{bc}$ & $0.554 \mathrm{a}-\mathrm{d}$ & $0.876 \mathrm{bc}$ & 0.310 cde & $47.023 \mathrm{~b}$ \\
\hline $25 \mathrm{YN}+75 \mathrm{YSS}(25 A+75 T)$ & $2.765 \mathrm{ab}$ & $0.697 \mathrm{a}$ & $0.982 \mathrm{abc}$ & 0.305 cde & $58.931 \mathrm{a}$ \\
\hline $25 \mathrm{YN}+75 \mathrm{Y}(25 A+75 O)$ & $2.607 \mathrm{abc}$ & $0.613 \mathrm{abc}$ & $0.955 \mathrm{abc}$ & 0.284 cde & $48.087 \mathrm{~b}$ \\
\hline
\end{tabular}

(**) 0.01 düzeyinde önemli; YN: Yonca, MF: Macar fiği; YŞ: Yem şalgamı; Y: Yulaf; K: Potasyum; P: Fosfor; Ca: Kalsiyum; Mg: Magnezyum; Fe: Demir; A; Alfalfa; HV: Hungarian vetch; T: Turnip; O: Oat.

Periguad, (1970) ruminant hayvanlar için yemlerdeki Fe içeriğinin en az 50 ppm olması gerektiğini bildirmiştir. Çalışmada aynı zamanda en yüksek Fe içeriğine sahip olan yalın Macar fiği (60.76 ppm), \% $75 \mathrm{YN}+25 \mathrm{Y}(51.383 \mathrm{ppm}), \% 50 \mathrm{YN}+50 \mathrm{Y}(51.766 \mathrm{ppm})$ ve $\% 25 \mathrm{YN}+75 \mathrm{YSS}$ (58.931 ppm) silajları bu seviyenin üzerinde olmuştur (Çizelge 4).

\section{SONUÇ}

$\mathrm{Bu}$ çalışma kapsamında, yonca ile Macar fiği, yem şalgamı ve yulafın yalın ve yonca ile 3 farklı karışım oranında silajları yapılmıştır. Yalın yoncanın silaj kalitesi açısından yetersiz kaldığı ancak, yulaf ve yem şalgamı ilavesinin silajın kalitesini olumlu yönde etkilediği tespit edilmiştir. Yonca ile Macar fiği karışımlarından yapılan silajların protein içerikleri diğer karışımlara göre daha yüksek çıkmış, ancak, bu silajların laktik asit içerikleri istenen seviyeden düşük çıktığından bu iki baklagilin silaj olarak değerlendirilmesinin uygun olmadığı tespit edilmiştir. Buna göre, silajların Flieg puanları ile ham protein 
oranları birlikte değerlendirildiğinde; yoncanın yem şalgamı ile tüm karışımları ve yoncanın yulaf ile \% $75+25$ karışımının silajının daha uygun olduğu sonucuna varılmıştır.

\section{TEŞEKKÜR}

$\mathrm{Bu}$ çalışmaya 2018-02.BŞEÜ.06-01 numaralı BAP projesi ile destek sağlayan Bilecik Şeyh Edebali Üniversitesi Bilimsel Araştırma Projeleri Koordinatörlüğü’ne teşekkür ederiz.

Çıkar çatışması beyanı

Yazarlar arasında çıkar çatışması yoktur.

\section{Yazar Katkı Oranları}

Yazarlar makaleye eşit oranda katkı sağladıklarını beyan ederler.

\section{KAYNAKLAR}

Alaca B, Parlak, AÖ 2017. Mısır, sorgum sudanotu melezi ile soya, börülce ve guarin karışık ekimlerinin silaj verimi ve kalitesine etkileri. ÇOMÜ Ziraat Fakültesi Dergisi, 5(1): 99-104.

Alçiçek A, Özkan K 1996. Silo Yemlerinde destilasyon yöntemi ile süt asidi, asetik asit ve bütirik asit tayini. Ege Üniversitesi Ziraat Fakültesi Dergisi, $3:(2-3): 191-198$.

Anonim 2018a. Bitkisel Üretim İstatistikleri. Türkiye İstatistik Kurumu. https://biruni.tuik.gov.tr/ medas $/$ kn $=92 \&$ locale $=\operatorname{tr}$

Anonim 2018b. Tarım ve Orman Bakanlığı. Yıllara göre yağış ortalaması. https://www.mgm.gov.tr/ veridegerlendirme/yillik-toplam-yagis-verileri.aspx

Başaran U, Gülümser E, Mut H, Çopur Doğrusöz M 2018. Mürdümük +Tahıl Karışımlarının Silaj Verimi ve Kalitesinin Belirlenmesi. Türk Tarım Gida Bilim ve Teknoloji Dergisi, 6(9): 1237-1242.

Can M, Kaymak G, Gülümser E, Acar Z, Ayan İ 2019. Orman üçgülü yulaf karışımlarının silaj kalitesinin belirlenmesi. Anadolu Tarım Bilimleri Dergisi, 34: 371-376.

Dumlu Gül Z, Tan M 2013. Baklagil Yem Bitkilerinin Silajlık Olarak Kullanılması. Atatürk Üniversitesi Ziraat Fakültesi Dergisi, 44(1): 189-193.
Ergin S 2019. Yonca Silajına Tuz Ve Laktik Asit Bakteri İnokulant İlavesinin Silaj Kalitesi, Fermantasyon Profili Ve Mikrobiyel Özellikleri Üzerine Etkileri. Burdur Mehmet Akif Ersoy Üniversitesi Sağllk Bilimleri Enstitüsü Hayvan Besleme ve Beslenme Hastalıkları Anabilim Dalı, Yüksek Lisans Tezi, 76 sy.

Filya İ 2001. Silaj teknolojisi. Hakan Ofset, İzmir.

Geren H, Kavut YT 2009. İkinci Ürün Koşullarında Yetiştirilen Bazı Sorgum (Sorghum sp.) Türlerinin Misır (Zea mays L.) ile Verim ve Silaj Kalitesi Yönünden Karşlaştırılması Üzerine Bir Araştırma. Ege Üniversitesi Ziraat Fakültesi Dergisi, 46(1): 916.

Gülümser E, Mut H, Başaran U, Çopur Doğrusöz M 2019. Melas veya Arpa Kırması İlavesinin Börülce ve Soya Silajlarının Kalitesi Üzerine Etkisi. BŞEÜ Fen Bilimleri Dergisi, 6(Özel sayl): 161-167.

Harmanşah F 2018. Türkiye'de Kaliteli Kaba Yem ve Sorunları ve Öneriler. TÜRKTOB Dergisi, 25: 9-13.

Keleş G, Alataş MS, Ateş S 2013. Silaj Katkıları ile Silolanmış Yonca ve Macar Fiği Silajlarının Besin Değeri ve Fermantasyon Özellikleri. VII. Ulusal Hayvan Besleme Kongresi, 26 - 27 Eylül, Ankara.

Kılı̧ A 1984. Silo yemi. Bilgehan Basımevi. İzmir.

Kidambi SP, Matches AG, Gricgs TC 1989. Variability for $\mathrm{Ca}, \mathrm{Mg}, \mathrm{K}, \mathrm{Cu}, \mathrm{Zn}$ and $\mathrm{K} /(\mathrm{Ca}+\mathrm{Mg})$ ratio among 3 wheat grasses and sainfoin on the southern high plains. Journal of Range Management, 42: 316-322.

Kutlu HR 2002. Tüm Yönleriyle Silaj Yapımı ve Silajla Besleme. Çukurova Üniversitesi, Balcalı-Adana.

Periguad S 1970. Les carences en oligo-elements chez les ruminants en france leurdiagnost.les problems souleves par l'intensification fourragere. Ann. Agron, 21: 635 - 669.

Tejada R, Codowell LR, Martin M FG, Concard JH 1985. Mineral element analyses of various tropical forages in Guatemala and their relationship to soil concentrations. Nutrition Reports International, 32: 313-323.

Uygur MA 2019. Silaj Kalitesinin Fiziksel ve Kimyasal Yöntemlerle Belirlenmesi. https://arastirma. tarimorman.gov.tr/etae/Belgeler/ EgitimBrosur/ 127-ciftcibro.pdf. 